\title{
KEEFEKTIFAN METODE BRAIN-BASED LEARNING TERHADAP MOTIVASI DAN PRESTASI BELAJAR SISWA PADA MATA PELAJARAN MATEMATIKA
}

\author{
Nurul Faqih Isro'i, Anik Ghufron \\ STKIP Muhammadiyah Bangka Belitung, Fakultas Ilmu Pendidikan UNY \\ nurulfaqih1990@gmail.com, anikgh@telkom.net
}

\begin{abstract}
Abstrak
Penelitian ini bertujuan untuk mendeskripsikan keefektifan metode brain-based learning terhadap motivasi dan prestasi belajar siswa pada mata pelajaran matematika kelas $X$ di madrasah aliyah. Penelitian ini merupakan penelitian eksperimen semu dengan rancangan one-group pretest-posttest design. Populasi penelitian adalah 272 siswa kelas X MA di Kabupaten Bangka. Sampel penelitian berjumlah 162 siswa. Instrumen penelitian yaitu angket untuk motivasi belajar dan tes pilihan ganda untuk prestasi belajar. Analisis data diawali dengan analisis deskriptif, dan untuk mendeskripsikan keefektifan pembelajaran dengan metode brain-based learning, data dianalisis dengan statistik uji t-test one sample pada taraf signifikansi 5\%. Hasil penelitian menunjukkan bahwa rata-rata skor motivasi dan prestasi belajar siswa meningkat setelah diberikan perlakuan. Rata-rata skor angket motivasi belajar awal yaitu 122,04 dan motivasi belajar akhir yaitu 168,98. Rata-rata skor tes prestasi belajar awal yaitu 45,16 dan rata-rata skor tes prestasi belajar akhir yaitu 75,36. Hasil uji one sample t-test yang diperoleh untuk variabel motivasi belajar yaitu 0,000 dan hasil belajar 0,000 , nilai $p$-value $\leq 0,05$, sehingga $\mathrm{H}_{0}$ ditolak dan $\mathrm{H}_{\mathrm{a}}$ diterima. Dapat disimpulkan bahwa pembelajaran matematika dengan metode BBL efektif untuk meningkatkan motivasi dan prestasi belajar siswa.
\end{abstract}

Kata kunci: brain-based learning, pembelajaran matematika, motivasi belajar, prestasi belajar

\section{THE EFFECTIVENESS OF USING BRAIN-BASED LEARNING METHOD IN THE MOTIVATION AND LEARNING ACHIEVEMENT AT MATHEMATICS}

\author{
Nurul Faqih Isro'i, Anik Ghufron \\ STKIP Muhammadiyah Bangka Belitung, Fakultas Ilmu Pendidikan UNY \\ nurulfaqih1990@gmail.com, anikgh@telkom.net
}

\begin{abstract}
The aim of this study is to determine the effectiveness of brain-based learning method in the motivation and learning achievement at mathematics of the tenth grade students of madrasah aliyah. This study was a quasi-experimental study using the one-group pretest-posttest design. It used one experimental group. The population was 272 tenth grade students of $M A$ in Kabupaten Bangka. The sample was 162 students. The instruments are a questionnaire for learning motivation and multiple choice tests for learning achievement. Firstly The data are analyzed with a descriptive analysis, then using the brain-based learning method to describe the effectiveness of the learning process. The data are analyzed using statistical one sample t-test at the significance level of $5 \%$. The result of the research shows that the score of motivation and learning achievement of the students at mathematics increased after using the brain-based learning method. The preliminary score of learning motivation questionnaire is 122.04 and the final score of learning motivation is 168.98. The preliminary score of learning achievement is 45.16 and the final score of learning achievement is 168.98. The result of one sample t-test for the variable of learning motivation is 0.000 and learning achievement is $0.000, p$ value $\leq 0.05$, therefore $\mathrm{H}_{0}$ is rejected and $\mathrm{Ha}$ is accepted. It can be concluded that teaching mathematics with BBL method is effective to increase the students' motivation and learning achievement.
\end{abstract}

Keywords: brain-based learning, mathematics learning process, learning motivation, learning achievement 


\section{Pendahuluan}

Pendidikan merupakan salah satu aspek yang sangat penting dalam kehidupan manusia. Bahkan ada pepatah yang mengatakan maju mundurnya suatu negara tergantung pada pendidikan yang diberikan kepada masyarakatnya. Namun, kualitas pendidikan di Indonesia sampai saat ini masih belum menggembirakan dan masih tertinggal jika dibandingkan dengan negara-negara lain. Menurut survey Political and Economic Risk Consultant (Wati, 2010, p.2), kualitas pendidikan di Indonesia berada pada urutan ke-12 dari 12 negara di Asia. Posisi Indonesia berada di bawah Vietnam. Pendidikan Indonesia belum banyak menghasilkan insan yang kreatif, mandiri dan tangguh. Salah satu faktor penyebab rendahnya pendidikan di negara kita adalah strategi pembelajarannya yang kurang efektif.

Pembelajaran yang dilakukan di lembaga-lembaga pendidikan formal saat ini masih banyak yang menggunakan strategi pembelajaran yang bersifat konvensional. Menurut penelitian Sunarto (2009), sekolah-sekolah di Jawa Tengah hampir $80 \%$ guru masih menggunakan pendekatan pembelajaran konvensional. Berdasarkan hasil survey yang dilakukan Ardhana (Mulyono, 2010) terhadap beberapa SD di Buleleng (Bali) dan kota Malang ditemukan bahwa $80 \%$ guru menyatakan paling sering menggunakan metode ceramah untuk pembelajaran sains. Sedangkan dari pandangan siswa, 90\% menyampaikan bahwa gurunya mengajar dengan cara menerangkan, 58,8\% berpendapat dengan cara memberikan PR, dan 43,6\% menyampaikan dengan cara meringkas, serta jarang sekali melakukan pengamatan di luar kelas. Salah satu mata pelajaran di SMA/MA yang masih menggunakan metode konvensional yaitu Matematika.

Matematika menempati posisi yang sangat penting dalam kurikulum sekolah di Indonesia sehingga harus diajarkan pada setiap jenjang pendidikan, yang mendasari perkembangan teknologi modern dan mampu mengembangkan daya pikir (Permendiknas, 2006, p.87). Menurut Fanu (Agustin, 2011, p.45), faktanya elemenelemen yang dibutuhkan dalam belajar matematika yaitu kemampuan membaca dan menulis, kemampuan membedakan suatu ukuran, kemampuan mengidentifikasi urutan-urutan, kemampuan menggunakan simbol-simbol abstrak, kemampuan aritmatika,kemampuan spatial, kemampuan menggunakan logika, short term and long term memory.

Pembelajaran matematika di SMA/ MA dipandang selalu memberikan tingkat kesulitan yang tinggi pada siswa. Menurut Johanes (2008), hal ini paling tidak disebabkan oleh dua kondisi: Pertama, terkait materi pelajaran. Materi yang harus dipelajari dalam matematika SMA/MA bersifat abstrak pada beberapa pokok bahasan, sehingga tidak dapat dikaitkan dengan kehidupan nyata siswa. Kedua, terkait proses pembelajaran. Pembelajaran yang konvensional (menerangkan dan mengerjakan latihan soal) tidak memberikan daya tarik bagi siswa, di dukung dengan materi pelajaran yang sulit, pembelajaran ini terjebak pada kondisi membosankan dan tidak memberi peluang siswa untuk belajar dengan rasa nyaman.

Pengajaran matematika pada tingkat menengah atas khususnya di tingkat Madrasah Aliyah di Kabupaten Bangka belum mencapai hasil yang optimal. Hal ini tercermin dari data hasil Ujian Nasional (UN) yang disajikan pada Tabel 1.

Berdasarkan hasil pengamatan penulis pada Madrasah Aliyah di Kabupaten Bangka (2013), pembelajaran matematika masih menggunakan metode pembelajaran konvensional. Hal ini ditandai dengan proses pembelajaran yang lebih banyak didominasi guru, sementara siswa lebih pasif. Selain itu, pembelajaran matematika yang diterapkan di sekolah tersebut kebanyakan membuat siswa tidak siap, karena siswa tidak mengetahui tujuan belajar yang sebenarnya, tidak mengetahui manfaat yang akan diperoleh setelah belajar. Selain itu, siswa kurang mendapat penghargaan 
terhadap hasil kerja mereka. Sehingga tujuan dari belajar belum dapat tercapai.

Tabel 1. Hasil UN MA 2012/2013

Kabupaten Bangka pada Mata Pelajaran Matematika

\begin{tabular}{lll}
\hline Nama Madrasah & Jurusan & $\begin{array}{l}\text { Nilai } \\
\text { UN }\end{array}$ \\
\hline MAN Sungailiat & IPS & 5,58 \\
& IPA & 5,56 \\
\hline MA Al Islam Kemuja & IPS & 5,54 \\
& IPA & 5,83 \\
& Keagamaan & 4,29 \\
\hline MA Nurul Ihsan Baturusa & IPS & 5,57 \\
\hline MA An Najah Payabenua & IPS & 5,69 \\
\hline MA An Najah Petaling & IPS & 6,05 \\
\hline MA Terpadu Sabilul Muhtadin & Keagamaan & 4 \\
\hline (Kemenag Kab. Bangka, 2013) &
\end{tabular}

Menurut pengakuan salah satu guru mata pelajaran matematika, banyaknya materi yang harus diselesaikan tiap semester, membuat guru tidak dapat terlalu memperhatikan kemampuan masingmasing siswa. Guru dituntut untuk dapat menyelesaikan dan melanjutkan materi, padahal siswa belum menguasai materi sebelumnya. Banyaknya kompetensi yang terdapat dalam bidang studi ini menyebabkan anak kesulitan menguasai persoalan matematis. Selain itu, metode pembelajaran yang digunakan cenderung konvensional (seperti ceramah dan pemberian tugas) yang kurang mampu menggali motivasi dan potensi anak. Metode ini masih dipertahankan, menurut guru tersebut karena dianggap lebih mudah dan cepat menyelesaikan materi belajar, walaupun siswa masih kesulitan dalam memahami materi. Hal ini menambah deret panjang faktor pemicu sulitnya anak memahami materi matematika (Wawancara Guru Matematika, 9 November 2013).

Situasi pembelajaran seperti ini jika terus dipertahankan akan membawa dampak yang kurang baik bagi siswa, dimana kondisi ini akan menimbulkan sikap kegagalan dan mempertahankan diri. Siswa akan merasa apa yang mereka kerjakan bukan merupakan apa yang mereka inginkan. Hal ini menyebabkan jika sesuatu yang terjadi di luar keinginan siswa, maka siswa akan berusaha untuk berbohong atau menutupi apa yang mereka rasakan dan alami dalam kegiatan pembelajaran. Kondisi ini jelas merupakan sebuah hal yang kontraproduktif terhadap terciptanya kegiatan pembelajaran yang bermakna bagi siswa.

Metode pembelajaran yang selama ini digunakan oleh pendidik, cenderung menekankan pada pola kerja otak kiri siswa saja. Padahal belajar dikatakan berhasil bila otak difungsikan secara optimal atau fungsi otak lebih optimal bila seluruh bagian otak dapat diaktifkan.

Setiap proses pembelajaran guru diharapkan dapat menggunakan metodemetode secara variatif sehingga siswa merasa nyaman dan menyenangkan dalam kegiatan belajar mengajar. Kegiatan pembelajaran tidak hanya dapat dilakukan di ruang kelas. Pembelajaran di tempat terbuka dapat menimbulkan kesan tersendiri bagi setiap siswa. Sehingga pembelajaran diharapkan dapat membentuk kecerdasan yang mengacu pada perkembangan otak siswa secara utuh (Mahfudz, 2012, p.99).

Perlu dilakukan suatu upaya untuk mengatasi permasalahan di atas, yaitu dengan menerapkan suatu metode pembelajaran yang dapat meningkatkan kemampuan siswa dan motivasi belajar siswa yang memungkinkan tercapainya ketuntasan belajar mengajar khususnya pada mata pelajaran matematika. Salah satu alternatif pemecahan masalah tersebut di atas yaitu dengan menggunakan inovasi pembelajaran yang berpijak pada proses kinerja otak yang dioptimalkan atau dikenal dengan brain-based learning (BBL). BBL menawarkan sebuah konsep untuk menciptakan pembelajaran dengan berorientasi pada upaya pemberdayaan potensi otak siswa. Pembelajaran dengan menggunakan metode BBL mampu meningkatkan kemampuan dan keterampilan individu sebagai efek pembelajaran. 
Tiga strategi utama yang dapat dikembangkan dalam implementasi brainbased learning; pertama, menciptakan lingkungan belajar yang menantang kemampuan berpikir siswa yaitu dengan memberikan soal-soal yang memfasilitasi kemampuan berpikir siswa berdasarkan Taxonomy Bloom. Kedua, menciptakan lingkungan pembelajaran yang menyenangkan, seperti melakukan pembelajaran di luar kelas, mengiringi kegiatan pembelajaran dengan musik, melakukan kegiatan pembelajaran dengan diskusi kelompok diselingi permainan-permainan menarik, dan lain sebagainya. Ketiga, menciptakan situasi pembelajaran yang aktif dan bermakna bagi siswa (active learning) yaitu dengan membangun situasi pembelajaran yang memungkinkan seluruh anggota badan siswa beraktivitas secara optimal. Pembelajaran merupakan proses sederhana yang harus dilakukan dan dialami sendiri oleh siswa untuk membangun pengetahuan dan kebermaknaan belajar.

Penelitian ini bertujuan untuk mendeskripsikan keefektifan metode brainbased learning pada mata pelajaran matematika dalam meningkatkan motivasi dan prestasi belajar siswa kelas X di Madrasah Aliyah. Hasil penelitian ini memberikan beberapa manfaat, yaitu: secara teoritis, hasil penelitian ini dapat menambah kajian lebih lanjut terkait penerapan BBL dalam pembelajaran di kelas. Secara praktis, bagi guru dapat digunakan sebagai bahan evaluasi guru sehingga prestasi siswa menjadi lebih baik. Bagi siswa penerapan metode dapat membantu dalam belajar dan memahami materi, dan bagi peneliti dapat digunakan sebagai masukan untuk penelitian selanjutnya dalam bidang yang sama maupun bidang lainnya.

\section{Metode Penelitian}

Jenis, Waktu dan Tempat Penelitian

Penelitian ini merupakan penelitian eksperimen semu (quasi experimental designs) dengan rancangan one-group pretestposttest design. Penelitian ini dilakukan tanpa menggunakan kelas kontrol atau pembanding. Hal ini karena setiap siswa/ kelas mempunyai karakteristik yang berbeda-beda dalam tingkat pemahamannya, sehingga kelas eksperimen tidak dapat dibandingkan dengan kelas kontrol meskipun perlakuan yang diberikan sama, tingkat pemahaman yang dicapai oleh siswa akan beragam setiap kelasnya.

Penelitian ini dilaksanakan pada siswa kelas X Madrasah Aliyah di Kabupaten Bangka. Pelaksanaan eksperimen dilakukan 2 (dua) tahap. Tahap pertama pada bulan Mei dan tahap kedua pada bulan September 2014.

\section{Target Penelitian}

Populasi penelitian ini yaitu seluruh siswa kelas X Madrasah Aliyah Kabupaten Bangka. Jumlah seluruh siswa kelas $X$ yaitu 272 dari 14 kelas. Penentuan jumlah sampel menggunakan metode Slovin, sehingga sampel penelitian berjumlah 162 siswa.

Prosedur Penelitian

Tahap-tahap pada penelitian ini meliputi: tahap persiapan, tahap pelaksanaan dan tahap akhir. Tahap persiapan, yaitu: pelatihan guru, membuat bahan pembelajaran, menyusun RPP, menyusun instrumen, menentukan waktu pelaksanaan, membuat surat izin. Tahap pelaksanaan meliputi: melakukan pretest, treatment, dan posttest. Tahap akhit meliputi: pengolahan dan analisis data hasil eksperimen, pembahasan, menyimpulkan dan melaporkan hasil penelitian. Desain penelitian dapat digambarkan sebagai berikut.

\section{$\mathrm{O}_{1} \mathrm{X} \mathrm{O}_{2}$}

Gambar 1. Desain Penelitian

Data, Instrumen, dan Teknik Pengumpulan Data

Data yang dibutuhkan dalam penelitian ini yaitu motivasi dan prestasi belajar siswa. Teknik pengumpulan data 
yang akan digunakan yaitu angket motivasi belajar, tes prestasi belajar, dan observasi.

\section{Teknik Analisis Data}

Analisis data diawali dengan analisis deskriptif, dan untuk mendeskripsikan keefektifan pembelajaran dengan metode brain-based learning, data dianalisis dengan statistik uji t-test one sample pada taraf signifikansi 5\%.

Data yang dideskripsikan merupakan data yang diperoleh dari pengukuran pada variabel-variabel penelitian (variabel terikat) yaitu motivasi belajar dan prestasi belajar. Data-data tersebut dihitung nilai rata-ratanya kemudian diinterpretasikan ke dalam kriteria-kriteria yang telah ditetapkan. Menurut Sudijono (2011, p.329), acuan pengubahan skor menjadi nilai standar berskala lima sebagaimana disajikan pada Tabel 2 .

Tabel 2. Kriteria Penilaian Ideal

\begin{tabular}{ccc}
\hline Interval & Nilai & Kriteria \\
\hline $\mathrm{Mi}+1,5 \mathrm{Si}<X \leq \mathrm{Mi}+3 \mathrm{Si}$ & $\mathrm{A}$ & Sangat tinggi \\
\hline $\mathrm{Mi}+0,5 \mathrm{Si}<X \leq \mathrm{Mi}+1,5 \mathrm{Si}$ & $\mathrm{B}$ & Tinggi \\
\hline $\mathrm{Mi}-0,5 \mathrm{Si}<X \leq \mathrm{Mi}+0,5 \mathrm{Si}$ & $\mathrm{C}$ & Sedang \\
\hline $\mathrm{Mi}-1,5 \mathrm{Si}<X \leq \mathrm{Mi}-0,5 \mathrm{Si}$ & $\mathrm{D}$ & Rendah \\
\hline $\mathrm{Mi}-3 \mathrm{Si}<X \leq \mathrm{Mi}-1,5 \mathrm{Si}$ & $\mathrm{E}$ & Sangat rendah \\
\hline
\end{tabular}

Pembelajaran matematika dengan metode brain-based learning terhadap motivasi dan prestasi belajar siswa dikatakan efektif jika skor rata-rata memperoleh kriteria tinggi dan sangat tinggi. Kriteria tinggi untuk motivasi belajar matematika yaitu rentang skor $160<X \leq 192$, sedangkan untuk prestasi belajar dengan kriteria sangat tinggi yaitu $75<X \leq 100$. Hipotesis yang diuji adalah sebagai berikut.

$\mathrm{H}_{0}: \mu_{1} \leq 160$

$\mathrm{H}_{\mathrm{a}}: \mu_{1}>160$

Hipotesis di atas artinya pembelajaran dengan metode brain-based learning tidak efektif untuk meningkatkan motivasi belajar siswa yaitu jika rata-rata siswa memperoleh skor $\leq 160$. Pembelajaran de- ngan metode brain-based learning efektif untuk meningkatkan motivasi belajar siswa jika skor $>160$.

$\mathrm{H}_{0}: \mu_{2} \leq 75$

$\mathrm{H}_{\mathrm{a}}: \mu_{2}>75$

Hipotesis di atas artinya pembelajaran dengan metode brain-based learning tidak efektif untuk meningkatkan prestasi belajar siswa yaitu jika rata-rata siswa memperoleh skor $\leq 75$. Pembelajaran dengan metode brain-based learning efektif untuk meningkatkan prestasi belajar siswa jika skor $>75$.

Hipotesis di atas merupakan hipotesis satu arah, yaitu hipotesis arah kanan. Pengujian hipotesis penelitian menggunakan one sample t-test dengan rumus berikut.

$t=\frac{\bar{x}-\mu_{0}}{s / \sqrt{n}}$, taraf signifikansi $5 \%$ atau 0,05 .

Pada penelitian ini dilakukan analisis multivariat sebelum uji hipotesis. Analisis multivariat bertujuan untuk mengetahui apakah terdapat perbedaan skor motivasi antara skor motivasi awal (pre) dan skor motivasi akhir (post), dan perbedaan skor prestasi antara skor prestasi awal (pretest) dan skor prestasi akhir (posttest). Jika terdapat perbedaan, maka dapat dilanjutkan dengan uji t.

Hasil uji menunjukkan angka signifikansi 0,000 untuk kedua variabel (motivasi dan prestasi). 0,000 < 0,05, maka Ha diterima. Artinya, terdapat perbedaan skor motivasi maupun prestasi antara skor awal (pre) dan skor akhir (post). Sehingga selanjutnya dapat dilakukan uji t.

Data penelitian juga dianalisis gain score. Analisis ini untuk mengetahui peningkatan atau perbedaan skor yang diperoleh dengan menghitung selisih antara skor pretest dan posttest. Penghitungan gain score menggunakan rumus berikut:

$$
g=\frac{\text { skor posttest }- \text { skor pretest }}{\text { skor maksimum }- \text { skor pretest }}
$$

(Hake, 1998; Meltzer)

Persentase peningkatan dihitung dengan rumus: 
$\frac{\text { skor posttest-skor pretest }}{\text { skor pretest }} \times 100 \%$

Hipotesis yang telah dirumuskan akan diuji dengan statistik parametris, yaitu dengan menggunakan $t$-test untuk satu sampel. Penggunaan statistik parametris mensyaratkan bahwa data setiap variabel yang akan dianalisis harus berdistribusi normal (Sugiyono, 2013, p.172). Oleh karena itu sebelum pengujian hipotesis dilakukan, maka perlu dilakukan pengujian normalitas data.

Uji normalitas pada penelitian ini bertujuan untuk mengetahui apakah data berdistribusi normal atau tidak. Pengujian dilakukan terhadap data hasil pretest dan posttest, meliputi data tes prestasi belajar dan angket motivasi belajar. Dalam penelitian ini, pengujian normalitas data menggunakan uji Kolmogrov Smirnov (K-S), dengan kriteria data berdistribusi normal jika $p \geq 0,05$. Uji normalitas dilakukan dengan menggunakan bantuan program SPSS 16.0 for windows.

\section{Hasil Penelitian dan Pembahasan}

Keefektifan merupakan ukuran tercapainya suatu tujuan. Pasal 1 UU Sisdiknas tahun 2003 menyatakan bahwa salah satu tujuan pendidikan nasional adalah mengembangkan potensi peserta didik untuk memilki kecerdasan, kepribadian dan akhlak mulia. UU tersebut bermaksud agar pendidikan tidak hanya membentuk insan Indonesia yang cerdas, namun juga berkepribadian atau berkarakter, sehingga nantinya akan lahir generasi bangsa yang tumbuh berkembang dengan karakter yang bernafas nilai-nilai luhur bangsa serta agama. Jadi keefektifan sebagai tingkat kesesuaian antara tujuan yang dicapai dengan rencana yang diharapkan. Pem-belajaran dikatakan efektif jika usaha dalam pembelajaran mencapai tujuan. Hal ini dapat diketahui dengan cara membandingkan antara kondisi yang diharapkan dengan kondisi yang dicapai.

Pencapaian pembelajaran yang efektif, maka guru juga harus efektif dalam mengajar. Menurut Rob Norris (Suryosubroto, 2002, p.14) mengajar yang efektif tergantung pada: (1) kepribadian guru, (2) metode yang dipilih, (3) pola tingkah laku, dan (4) kompetensi yang relevan. Metode pembelajaran yang dipilih harus secara efektif dapat digunakan dalam pencapaian hasil yang optimal.

Salah satu metode yang dapat digunakan yaitu metode brain-based learning (BBL). BBL menawarkan sebuah konsep untuk menciptakan pembelajaran dengan berorientasi pada upaya pemberdayaan potensi otak siswa.

Motivasi belajar dan prestasi belajar matematika di Madrasah Aliyah Kabupaten Bangka sebelum diberikan treatment metode brain based learning belum sesuai dengan yang diharapkan. Prestasi belajar siswa masih tergolong rendah. Hal ini terlihat dari nilai rata-rata hasil belajar siswa yang belum mencapai nilai kriteria ketuntasan minimal (KKM). Motivasi yang dimilki siswa juga masih rendah. Hal ini terlihat pada saat peneliti melakukan observasi pada saat pembelajaran berlangsung sebelum penelitian dilakukan, dimana masih banyak siswa yang tidak memberikan perhatian selama pembelajaran. Hasil angket motivasi awal juga menunjukkan ratarata skor angket motivasi siswa berada pada kategori rendah. Hal tersebut di atas berakibat pembelajaran matematika belum berjalan dengan efektif.

Metode BBL telah di uji keefektifannya terhadap motivasi dan prestasi belajar pada mata pelajaran matematika di Madrasah Aliyah kabupaten Bangka. Data penelitian diperoleh dengan cara pretest dan posttest, data motivasi belajar melalui angket motivasi belajar berjumlah 48 item pernyataan dan data prestasi belajar melalui tes prestasi belajar berjumlah 25 item soal.

Data hasil penelitian menunjukkan bahwa rata-rata hasil pengukuran motivasi belajar sebelum perlakuan yaitu 122,04 dengan kriteria motivasi belajar rendah, sedangkan setelah perlakuan yaitu 168,98 dengan kriteria motivasi belajar tinggi. 
Frekuensi dan persentase banyak siswa pada setiap kriteria motivasi belajar dihitung sebagaimana rentang skor yang telah ditentukan. Distribusi frekuensi dan persentase pengukuran motivasi belajar sebelum dan setelah perlakuan disajikan pada tabel berikut.

Tabel 3. Distribusi Frekuensi dan Persentase Pengukuran Motivasi Belajar

\begin{tabular}{cccccc}
\hline \multirow{2}{*}{ Skor } & \multirow{2}{*}{ Kriteria } & \multicolumn{2}{c}{ Frek. } & \multicolumn{2}{c}{ Persentase } \\
\cline { 3 - 6 } & & Pre & Post & Pre & Post \\
\hline $192<X \leq 240$ & Sangat tinggi & 0 & 24 & $0 \%$ & $14,82 \%$ \\
$160<X \leq 192$ & Tinggi & 2 & 66 & $1,23 \%$ & $40,74 \%$ \\
$128<X \leq 160$ & Sedang & 46 & 72 & $28,4 \%$ & $44,44 \%$ \\
$96<X \leq 128$ & Rendah & 108 & 0 & $66,67 \%$ & $0 \%$ \\
$48 \leq X \leq 96$ & Sangat rendah & 6 & 0 & $3,7 \%$ & $0 \%$ \\
\hline
\end{tabular}

Tabel motivasi belajar di atas menunjukkan skor hasil angket motivasi belajar dan frekuensi tiap kriteria sebelum dan setelah diberikan perlakuan penerapan metode brain-based learning. Sebelum diberikan perlakuan tabel di atas menunjukkan tidak ada siswa yang berada pada skor $192<$ $X \leq 240$ (kriteria sangat tinggi), 2 siswa berada pada kriteria tinggi, 46 siswa pada kriteria sedang, 108 siswa pada kriteria rendah, dan 6 siswa pada kriteria sangat rendah. Setelah diberikan perlakuan, 24 siswa berada pada kriteria sangat tinggi, 66 siswa pada kriteria tinggi, 72 siswa pada kriteria sedang, tidak ada siswa yang berada pada kriteria rendah dan sangat rendah.

Berdasarkan pemaparan terkait hasil angket motivasi belajar di atas, motivasi belajar siswa sebelum perlakuan dan setelah perlakuaan mengalami peningkatan. Persentase hasil angket motivasi sebelum perlakuan terbesar berada pada kriteria motivasi rendah yaitu sebesar 66,67\%, setelah diberikan perlakuan persentase hasil angket motivasi terbesar berada pada kriteria motivasi tinggi 40,74\% dan sedang $44,44 \%$.
Distribusi frekuensi dan persentase pengukuran prestasi belajar sebelum dan setelah perlakuan disajikan pada tabel berikut.

Tabel 4. Distribusi Frekuensi dan Persentase Pengukuran Prestasi Belajar

\begin{tabular}{cccccc}
\hline \multirow{2}{*}{ Skor } & Kriteria & \multicolumn{2}{c}{ Frekuensi } & \multicolumn{2}{c}{ Persentase } \\
\cline { 3 - 6 } & & $\begin{array}{c}\text { Pre- } \\
\text { test }\end{array}$ & $\begin{array}{c}\text { Post- } \\
\text { test }\end{array}$ & $\begin{array}{c}\text { Pre- } \\
\text { test }\end{array}$ & $\begin{array}{c}\text { Post- } \\
\text { test }\end{array}$ \\
\hline $75<X \leq 100$ & Sangat tinggi & 0 & 94 & $0 \%$ & $58,0 \%$ \\
$58<X \leq 75$ & Tinggi & 12 & 68 & $7,41 \%$ & $41,9 \%$ \\
$42<X \leq 58$ & Sedang & 94 & 0 & $58,0 \%$ & $0 \%$ \\
$25<X \leq 42$ & Rendah & 56 & 0 & $34,5 \%$ & $0 \%$ \\
$0 \leq X \leq 25$ & Sangat rendah & 0 & 0 & $0 \%$ & $0 \%$ \\
\hline
\end{tabular}

Tabel prestasi belajar di atas menunjukkan skor tes prestasi belajar dan frekuensi tiap kriteria sebelum dan setelah diberikan perlakuan penerapan metode brain-based learning. Sebelum perlakuan, tidak ada siswa yang berada pada kriteria sangat tinggi maupun sangat rendah, 12 siswa berada pada kriteria tinggi, 94 siswa pada kriteria sedang, dan 56 siswa pada kriteria rendah. Setelah diberikan perlakuan penerapan metode brain-based learning, tidak ada siswa yang berada pada kriteria sedang, rendah dan sangat rendah, 68 siswa berada pada kriteria tinggi, dan 94 siswa berada pada kriteria sangat tinggi.

Berdasarkan pemaparan terkait tes prestasi belajar di atas, prestasi belajar siswa sebelum dan setelah perlakuaan mengalami peningkatan. Dari hasil pretest persentase terbesar berada pada kriteria prestasi belajar sedang yaitu $58,02 \%$, sedangkan persentase hasil posttest terbesar berada pada kriteria sangat tinggi yaitu $58,02 \%$.

Analisis data dalam penelitian ini terdiri dari pengujian hipotesis yang berkaitan dengan keefektifan pembelajaran matematika dengan metode brain-based learning untuk meningkatkan motivasi dan prestasi belajar siswa. Adapun kriteria keefektifan pembelajaran matematika dengan 
menggunakan metode BBL pada aspek motivasi belajar yaitu siswa memperoleh skor lebih dari 160, sedangkan untuk aspek prestasi belajar yaitu siswa memperoleh skor lebih dari 75. Hasil perhitungan skor rata-rata siswa setelah perlakuan (treatment) diperoleh skor rata-rata 75,36 untuk aspek prestasi belajar dan 168,98 untuk aspek motivasi belajar. Berdasarkan skor rata-rata siswa tersebut dapat dikatakan penggunaan metode brain-based learning pada mata pelajaran matematika materi ruang dimensi tiga efektif ditinjau dari aspek motivasi dan prestasi belajar.

Uji hipotesis keefektifan (uji hipotesis one sample t-test) dilakukan untuk mengetahui keefektifan metode brain-based learning yang digunakan dalam pembelajaran, yaitu dilihat dari acuan kriteria ideal. Acuan kriteria ideal dibuat berdasarkan data dan rata-rata yang diperoleh siswa yang diinterpretasikan ke dalam kriteriakriteria tertentu. Skor dikategorikan menjadi nilai standar berskala lima, dengan kriteria sangat tinggi, tinggi, sedang, rendah dan sangat rendah. Acuan pengubahan skor berdasarkan buku Sudjiono (2011, p.329). Kriteria keefektifan pembelajaran matematika dengan menggunakan metode BBL untuk meningkatkan motivasi belajar yaitu siswa memperoleh skor > 160, sedangkan untuk aspek prestasi belajar yaitu siswa memperoleh skor $>75$. Keefektifan pembelajaran dapat dilihat pada Tabel 5 .

Tabel 5. Keefektifan Pembelajaran dengan Metode Brain-Based Learning

\begin{tabular}{lcccl}
\hline Variabel & Interval & Jumlah & IK (\%) & \multicolumn{1}{c}{ Kriteria } \\
\hline Motivasi & $X \leq 160$ & 72 & $44,44 \%$ & Tidak tuntas \\
Belajar & $X>160$ & 90 & $55,56 \%$ & Tuntas \\
Hasil & $X \leq 75$ & 68 & $41,98 \%$ & Tidak tuntas \\
Belajar & $X>75$ & 94 & $58,02 \%$ & Tuntas \\
\hline
\end{tabular}

Ket: IK = Indeks Keefektifan

Tabel di atas menunjukkan bahwa 90 siswa pada kelompok eksperimen memperoleh skor lebih dari atau sama dengan 160 untuk aspek motivasi dan 94 siswa memperoleh skor lebih dari atau sama dengan 75 pada aspek prestasi belajar. Persentase indeks keefektifan untuk motivasi belajar yaitu $55,56 \%$ siswa tuntas, sedangkan untuk prestasi belajar yaitu 58,02\% siswa tuntas. Lebih dari $50 \%$ siswa tuntas untuk motivasi dan prestasi belajar.

Berdasarkan analisis deskriptif dengan data yang berasal dari angket motivasi siswa menunjukkan motivasi belajar siswa meningkat setelah diberikan perlakuan penerapan metode brain-based learning (BBL), sama halnya dengan prestasi belajar siswa, terdapat perbedaan skor antara pretest dan posttest yang mengalami peningkatan. Hasil ini sejalan dengan berbagai hasil penelitian yang telah dilakukan sebelumnya terkait penerapan metode BBL.

Pada penelitian yang dilakukan Qiqi Yuliati dalam desertasinya yang berjudul Implementasi Pembelajaran Berbasis Kemampuan Otak (Brain-Based Leraning) untuk Meningkatkan Kemampuan Berpikir Kritis Siswa (Studi Kuasi Eksperimen pada Siswa Sekolah Dasar di Kota Bandung), menunjukkan adanya peningkatan capaian rata-rata (gain) skor siswa yang relatif besar pada kelas eksperimen. Perhitungan uji beda dua rata-rata juga menunjukkan perbedaan yang signifikan antara skor ratarata pretest dan posttest. Hasil penelitian membuktikan bahwa pembelajaran BBL efektif meningkatkan kemampuan berpikir kritis siswa.

Selain itu terdapat penelitian-penelitian lainnnya yang mendukung hasil penelitian yang telah dilakukan salah satunya yaitu penelitian yang dilakukan oleh Ambar Prawoto, dkk yang berjudul Pembelajaran Dengan Pendekatan Brain-Based Learning untuk Meningkatkan Hasil Belajar Matematika Siswa SMP. Hasil penelitian menunjukkan bahwa hasil belajar siswa yang mendapatkan pembelajaran dengan pendekatan brain-based learning lebih baik dibandingkan dengan siswa yang mendapatkan pembelajaran secara konvensional.

Sejalan dengan teori terkait pembelajaran berbasis otak yang dapat meningkatkan keterlibatan kelas, menyalami se- 
mua siswa dengan senyum, meningkatkan koneksi sosial, dan mendorong keterlibatan dalam aktivitas sekolah, sehingga memberikan efek pada peningkatan motivasi siswa (Jensen, 2011, p.7). Hasil penelitian ini pun menunjukkan hal serupa dimana setelah diberikan pembelajaran menggunakan metode BBL skor rata-rata motivasi siswa mengalami peningkatan.

Selanjutnya dilakukan uji one sample t-test untuk melihat keefektifan dari metode pembelajaran yang digunakan. Hipotesis yang diuji yaitu:

$\mathrm{H}_{0}$ : Pembelajaran matematika dengan metode brain-based learning tidak efektif untuk meningkatkan motivasi dan prestasi belajar siswa.

$\mathrm{H}_{\mathrm{a}}$ : Pembelajaran matematika dengan metode brain-based learning efektif untuk meningkatkan motivasi dan prestasi belajar siswa.

Tabel 6. Hasil Uji One Sample T-Test Keefektifan Pembelajaran

\begin{tabular}{lllcc}
\hline \multicolumn{2}{c}{ Aspek } & $\mathrm{t}$ & $\mathrm{df}$ & Sig. \\
\hline Motivasi & Awal & 107,965 & 161 & 0,000 \\
Belajar & Akhir & 113,595 & 161 & 0,000 \\
\hline Prestasi & Awal & 70,162 & 161 & 0,000 \\
Belajar & Akhir & 127,458 & 161 & 0,000 \\
\hline
\end{tabular}

Tabel di atas menunjukkan bahwa signifikansi hasil uji one sample t-test yang diperoleh untuk variabel motivasi belajar yaitu 0,000 dan prestasi belajar 0,000. Signifikansi dari aspek motivasi maupun hasil belajat tersebut kurang dari 0,05. Nilai p-value $\leq 0,05$ maka $\mathrm{H}_{0}$ ditolak dan $\mathrm{H}_{\mathrm{a}}$ diterima. Hal ini berarti bahwa pembelajaran matematika dengan metode brainbased learning efektif untuk meningkatkan motivasi dan prestasi belajar siswa.

Dari hasil uji hipotesis yang telah dilakukan dengan uji-t pada taraf signifikansi 0,05 terdapat perbedaan yang signifikan antara skor motivasi belajar sebelum dan sesudah perlakuan, sama halnya dengan skor yang diperoleh dari prestasi belajar. Skor dari hasil angket motivasi belajar dan tes prestasi belajar setelah perlakuan mengalami peningkatan.

Hasil analisis gain score untuk aspek motivasi yaitu 0,52 dengan persentase pencapaian peningkatan 38,46\%. Pada aspek prestasi belajar diperoleh gain score yaitu 0,64 dengan persentase pencapaian peningkatan $66,87 \%$. Selengkapnya dapat dilihat pada tabel berikut.

Tabel 7. Hasil Perhitungan Gain Score dan Persentase Peningkatan

\begin{tabular}{lcc}
\hline \multicolumn{1}{c}{ Aspek } & Gain Score & $\begin{array}{c}\text { Persentase } \\
\text { Peningkatan }\end{array}$ \\
\hline Motivasi & 0,52 & $38,46 \%$ \\
Prestasi & 0,64 & $66,87 \%$ \\
\hline
\end{tabular}

Sebelum pengujian hipotesis penelitian dilaksanakan terlebih dahulu dilakukan pengujian persyaratan analisis yang meliputi uji normalitas data. Uji normalitas dilakukan untuk mengetahui apakah populasi berdistribusi normal atau tidak. Jenis pengujian pada penelitian ini yaitu uji Kolmogrov Smirnov (K-S). Pengujian dilakukan terhadap data motivasi dan prestasi belajar baik sebelum atau setelah perlakuan. Kriteria pengujian yaitu data berdistribusi normal jika $p \geq 0,05$. Uji normalitas dilakukan dengan menggunakan bantuan program SPSS 16.0 for windows.

Tabel 8. Hasil Uji Normalitas

\begin{tabular}{llccl}
\hline & & \multicolumn{2}{c}{ K-S } & Kesimpulan \\
\cline { 3 - 4 } & & Statistic & Sig & \\
\hline Motivasi & Pre & 0,070 & 0,052 & Normal \\
& Post & 0,132 & 0,000 & Normal \\
\hline \multirow{2}{*}{ Prestasi } & Pre & 0,186 & 0,000 & Normal \\
& Post & 0,201 & 0,000 & Normal \\
\hline
\end{tabular}

Berdasarkan tabel di atas dapat dilihat nilai signifikansi hasil perhitungan p-value pada masing-masing aspek $\geq 0,05$. Sehingga data-data tersebut berasal dari populasi yang berdistribusi normal memenuhi asumsi untuk dilakukan uji statistik parametrik. 
Berdasarkan kriteria keefektifan pembelajaran yang terkait dengan motivasi dan prestasi belajar siswa setelah mendapat perlakuan yaitu pembelajaran matematika dengan metode brain-based learning, maka dinyatakan pembelajaran tersebut merupakan pembelajaran yang efektif dalam upaya meningkatkan motivasi dan prestasi belajar siswa. Pelaksanaan pembelajaran matematika dengan BBL mengkondisikan belajar siswa dengan mula-mula mengaitkan pelajaran dengan keadaan nyata yang dijumpai sehari-hari ataupun suatu keadaan yang dapat dijangkau pikiran siswa.

Siswa SMA/MA umumnya tertarik untuk bersaing dalam beberapa hal termasuk yang terkait dengan pembelajaran matematika. Peran guru sebagai fasilitator dapat digunakan untuk membantu siswa yang merasa kesulitan atau kurang percaya diri dalam memecahkan masalah terkait mata pelajaran matematika. Guru hendaknya tidak marah bila siswa melakukan kesalahan, sebaliknya siswa didorong untuk tidak takut mencoba, karena belajar dari kesalahan akan bermakna daripada tidak melakukan apa-apa. Soal-soal terapan dapat diberikan sebanyak mungkin pada siswa dengan catatan soal-soal tersebut harus berjenjang tingkat kesulitannya. Siswa dibiasakan memecahkan masalah-masalah sederhana diteruskan ke masalah-masalah kompleks. Hal ini dapat meningkatkan motivasi dan prestasi belajar siswa.

Tahapan-tahapan yang ada pada Pembelajaran Berbasis Otak, di susun agar dapat mengoptimalkan fungsi-fungsi otak siswa dalam belajar. Sehingga pembelajaran menjadi lebih bermakna dan diharapkan dapat berdampak pada peningkatan prestasi belajar siswa.

Menurut Jensen (2011, p.233), tahap persiapan pada BBL memberikan satu kerangka kerja untuk pembelajaran baru, dan melengkapi otak pembelajar dengan koneksi yang memungkinkan. Semakin banyak latar belakang yang dimilki pembelajar terkait materi pelajaran, semakin cepat mereka menyerap dan mengolah informasi baru. Contoh lain pada tahap elaborasi, yaitu mengeksplorasi keterkaitan topik dan mendorong kedalaman pemahaman. Kemudian dilanjutkan dengan pembentukan memori yaitu merekatkan pelajaran, sehingga apa yang dipelajari pada hari ini dapat diingat kembali pada hari berikutnya. Akhirnya tahap integrasi fungsional mengingatkan pembelajar untuk menggunakan pembelajaran baru, sehingga dapat mengukuhkan lebih lanjut materi dan memperluasnya.

Penerapan Pembelajaran Berbasis Otak melalui tahapan-tahapan yang ada di dalamnya tersebut telah memberikan dampak positif terhadap pembelajaran di kelas. Pada penelitian yang telah dilakukan menghasilkan temuan-temuan terkait aspek hasil belajar dan motivasi belajar siswa. Adapun temuan penelitian ini sebagai berikut: (1) terdapat peningkatan skor prestasi belajar setelah diberikan pembelajaran dengan metode brain-based learning; (2) terdapat peningkatan skor motivasi belajar setelah diberikan pembelajaran dengan metode brain-based learning.

Berdasarkan hasil penelitian dan pembahasan yang telah dipaparkan di atas, metode brain-based learning efektif untuk diterapkan pada mata pelajaran matematika kelas $X$ materi ruang dimensi tiga ditinjau dari aspek motivasi dan prestasi belajar siswa. Oleh karena itu, metode BBL dapat menjadi salah satu alternatif metode dalam pembelajaran matematika.

\section{Simpulan dan Saran}

Berdasarkan hasil analisis data dan pembahasan, menunjukkan bahwa ratarata skor motivasi dan prestasi belajar siswa meningkat setelah diberikan pembelajaran matematika dengan metode brainbased learning. Nilai p-value dari hasil uji one sample t-test yang diperoleh untuk variabel motivasi belajar dan prestasi belajar $\leq 0,05$, maka dapat disimpulkan metode brain based learning efektif untuk meningkatkan motivasi dan prestasi belajar siswa pada 
mata pelajaran matematika kelas X Madrasah Aliyah.

Adapun saran yang dapat diajukan yaitu bagi guru dan peneliti. Guru dapat menerapkan metode brain-based learning sebagai salah satu alternatif metode dalam pembelajaran matematika, karena metode BBL efektif diterapkan untuk meningkatkan motivasi dan prestasi belajar siswa. Peneliti selanjutnya dapat menggunakan kelas kontrol dengan melibatkan metode inovatif lain yang setara untuk dibandingkan dengan metode BBL sehingga dapat menambah wawasan keilmuan. Selain itu, peneliti selanjutnya dapat melibatkan variabel terikat lainnya selain motivasi dan prestasi belajar dalam penerapan meode BBL untuk dilihat keefektifannya dan dapat menggunakan materi lainnya selain ruang dimensi tiga.

\section{Daftar Pustaka}

Agustin, M. (2011). Permasalahan belajar dan inovasi pembelajaran. Bandung: PT Refika Aditama.

Jensen, E. 2008. Brain based learning: The new science of teaching $\mathcal{E}$ training (Rev. ed.). (Terjemahan Narulita Yusron). California: Corwin Press. (Buku asli diterbitkan tahun 2007)

Johanes. (2008). Pembelajaran matematika beralur peta konsep. Diambil pada tanggal 17 juli 2014, dari http:// pkab. wordpress.com/2008/03/13/ pembelajaran -matematika-beralurpeta-konsep/

Mahfudz, A. 2012. Cara cerdas mendidik yang menyenangkan berbasis super quantum teaching. Jakarta: Simbiosa Rekatama Media.
Meltzer, D. E. The relationship between mathematics preparation and conceptual learning gains in physics: A possible .hidden variable. in diagnostic pretest scores. Department of Physics and Astronomy, Iowa State University. Diambil pada tanggal 12 November 2013, dari http://www. physicseducation.net/docs/ Addendum_on_normalized_gain.p $\mathrm{df}$

Mulyono, T. (2010). Pembelajaran konvensional. Diambil pada tanggal 12 April 2014, dari: http:/ / sdtrimulyo. blogspot.com/2010/02/ardhana-etal-2004-dari-hasil survei.html

Peraturan Menteri Pendidikan Nasional RI Nomor 22, Tahun 2006, tentang Standar Isi.

Sudijono, A (2011). Pengantar evaluasi pendidikan. Ed.1 Cet.11. Jakarta: PT Raja Grafindo Persada.

Sugiyono. (2013). Metode penelitian pendidikan: pendekatan kuantitatif, kualitatif, dan RED. Bandung: Alfabeta.

Sunarto. 2009. "Pembelajaran konvensional banyak dikritik namun paling disukai". Diakses dari: http://sunartombs. wordpress.com/2009/03/02/pemb elajaran-konvensional-banyakdikritik-namun-paling-disukai/

Suryosubroto. (2002). Proses belajar mengajar di sekolah. Jakarta: Rineka Cipta.

Wati, W. (2010). Makalah: Strategi pembelajaran permasalahan pendidikan di Indonesia. Diambil dari: widya57physicedu.files.wordpress. com/.../no-29-widya-wati-10masalah-pendidikan.pdf 